\title{
Analisis Hubungan Beban Kerja Mental dengan Kinerja Operator Proses Produksi bagian Purified Terephtalic Acid (PTA) di PT Mitsubishi Chemical Indonesia
}

\author{
Anita Dyah Juniarti ${ }^{1}$, Nur Trisno ${ }^{2}$ \\ Program Studi Teknik Industri Fakulta Teknik Universitas Banten Jaya \\ Jl. Ciwaru Raya II No. 73, Kel. Cipare, Kec. Serang, Kota Serang 42117 \\ anitadyahjuniarti@unbaja.ac.id
}

\begin{abstract}
This study discusses the relationship of mental workload of the operator of the production process of the Purified Terephthalic Acid (PTA) section at PT. Mitsubishi Chemical Indonesia. The purpose of this study is to measure and determine the relationship of mental workload with operator performance. The approach used is a quantitative approach with a survey method for all operators of the production process, amounting to 32 respondents. In this study shows that operator workload tends to be high, this can be seen from the scale of respondents answers to the dimensions of workload measurement that is the scale of respondents answers high to the dimensions of time load, the scale of respondents answers is very high on the dimensions of mental business load and the scale of respondents answers is high to the dimensions burden of psychological distress. The relationship between mental workload on the performance of the operator of the production process shows a significant result between the two where the strength of the relationship is strong and the direction of the relationship is positive, with the correlation value of the rank spearman coefficient of +0.755 . Respondents answers to mental workload variables indicate an indication of mental workload that is high, performance variables are also high. So, it can be concluded that the production process operator has a high mental workload and produces high performance. The results of this study also indicate that the operator's performance in high conditions, this can be seen from the scale of respondents 'answers to the dimensions of performance measurement, namely the scale of respondents' answers very high to the dimensions of quality, the scale of respondents answers to the dimensions of quantity high, the scale of respondents answers to the dimensions use of time at work, and the scale of respondents answers is very high on the dimensions of cooperation at work. Therefore, there is no improvement in performance.
\end{abstract}

Keywords: Mental Workload, Employee Performance, Rank Spearman Correlation

\begin{abstract}
ABSTRAK
Penelitian ini membahas hubungan beban kerja mental operator proses produksi bagian Purified Terephtalic Acid (PTA) di PT. Mitsubishi Chemical Indonesia. Tujuan dari penelitian ini untuk mengukur dan mengetahui hubungan beban kerja mental dengan kinerja operator. Pendekatan yang digunakan adalah pendekatan kuantitatif dengan metode survei terhadap seluruh operator proses produksi yang berjumlah 32 responden. Pada penelitian ini menunjukkan bahwa beban kerja operator cenderung tinggi, ini bisa dilihat dari skala jawaban responden terhadap dimensi pengukuran beban kerja yaitu skala jawaban responden tinggi terhadap dimensi beban waktu, skala jawaban responden sangat tinggi terhadap dimensi beban usaha mental dan skala jawaban responden tinggi terhadap dimensi beban tekanan psikologis. H ubungan yang ada antara beban kerja mental terhadap kinerja operator proses produksi menunjukkan hasil yang signifikan diantara keduanya dimana kekuatan hubungannya kuat dan arah hubungannya positif, dengan nilai korelasi koefisien rank spearman-nya yaitu $+0,755$. Jawaban responden atas variabel beban kerja mental menunjukkan indikasi beban kerja kerja mental yang tergolong tinggi, variabel kinerja juga tergolong tinggi. Sehingga dapat disimpulkan bahwa operator proses produksi memiliki beban kerja mental yang tinggi dan menghasilkan kinerja yang tinggi. Hasil dari penelitian ini juga menunjukkan bahwa kinerja operator dalam kondisi tinggi, hal ini bisa dilihat dari skala jawaban responden terhadap dimensi pengukuran kinerja yaitu dengan skala jawaban responden sangat tinggi terhadap dimensi kualitas, skala jawaban responden tinggi
\end{abstract}


terhadap dimensi kuantitas, skala jawaban responden tinggi terhadap dimensi penggunaan waktu dalam bekerja, dan skala jawaban responden sangat tinggi terhadap dimensi kerjasama dalam bekerja. Dengan demikian tidak dilakukan perbaikan dalam hal kinerja.

Kata Kunci: Beban Kerja Mental, Kinerja Operator, Korelasi Rank Spearman

\section{PENDAHULUAN}

\subsection{Latar Belakang}

Dalam era kompetisi sekarang ini, setiap perusahaan harus mampu meningkatkan kinerja perusahaan. Salah satu faktor penting yang harus diperhatikan oleh perusahaan dalam mencapai tujuannya adalah faktor sumber daya manusia (SDM). Manusia sebagai penggerak perusahaan merupakan faktor utama karena eksistensi perusahaan tergantung pada manusia-manusia yang terlibat dibelakangnya. Untuk dapat mencapai tujuan dari perusahaan maka diperlukan sumber daya manusia yang kompeten dalam melaksanakan tugasnya.

Bagi setiap perusahaan, karyawan bagian produksi merupakan sumber daya yang tidak kalah pentingnya dengan sumber daya perusahaan bagian yang lainnya. Karyawan dalam setiap organisasi memiliki tuntutan tugas-tugas yang merupakan salah satu aspek dari beban kerja. Beban kerja dapat didefinisikan sebagai perbedaan kemampuan pekerja dengan tuntutan pekerjaan (Hancock, P.A \& Meshkati, N. 1988). Jika kemampuan pekerja lebih tinggi daripada tuntutan pekerjaan, akan muncul perasaan bosan. Sebaliknya, jika kemampuan pekerja lebih rendah daripada tuntutan pekerjaan, maka akan muncul kelelahan.

Beban kerja menjadi salah satu indikasi penimbul stress, secara sederhana stress dipandang sebagai sesuatu yang melibatkan interaksi antara individu dengan lingkungan (Gibson, 1985). Dalam situasi kerja dikenal istilah stress kerja, menurut Wijono (2010) stres kerja merupakan suatu kondisi dari hasil penghayatan subjektif individu yang dapat berupa interaksi antara individu dan lingkungan kerja yang dapat mengancam dan memberikan tekanan secara psikologis, fisiologis, dan sikap individu, stress kerja ini menimbulkan permasalahan atau gejala dalam lingkungan pekerjaan, gejala-gejala fisiologi, psikologi maupun sikap. Perubahan fisiologi ditandai oleh adanya gejala-gejala seperti merasa lelah atau letih, kehabisan tenaga, pusing, gangguan pencernaan, sedangkan gejala psikologi yaitu kecemasan berlarut-larut dan sulit tidur, sedangkan perubahan sikap ditunjukan dengan keras kepala, mudah marah, dan tidak puas dengan apa yang dicapai.

PT Mitsubishi Chemical Indonesia (MCCI) adalah industri kimia yang bergerak di bidang petrokimia, dengan kata lain perusahaan tersebut mengelola bahan-bahan yang berskala dari fraksi minyak bumi. PT Mitsubishi Chemical Indonesia merupakan perusahaan asing yang memproduksi Asam Tereftalat (Purified Terephthalic Acid / PTA) yang menjadi bahan baku utama pembuatan polyester. Industri yang memproduksi PTA merupakan industri yang sarat akan modal. Meski demikian, bagian-bagian signifikansi dari produksinya membutuhkan input manusia. Produksi yang sesuai target serta kualitas yang baik merupakan kebutuhan perusahaan agar dapat terus bersaing dan mengibarkan benderanya.

Ada beberapa perusahaan di daerah Cilegon yang memproduksi PTA, diantaranya yaitu PT. Amoco Mitsui PTA Indonesia dan PT. Indorama Petrochemicals. Perusahaanperusahaan tersebut merupakan perusahaan pesaing dari MCCI yang memiliki tingkat kapasitas produksi yang tinggi. Posisi ini membuat perusahaan harus berusaha keras mempertahankan kapasitas produksi dan kualitas produknya agar terus dapat diterima oleh konsumen, masalah ini berhubungan dengan seksi produksi yang bertugas menjaga kestabilan proses produksi dengan baik. Pekerjaan ini menuntut ketelitian dan pengawasan ekstra agar menghasilkan produk sesuai dengan yang diinginkan.

Bidang kerja di seksi proses produksi di bagian Purified Terephtalic Acid (PTA) menuntut kebutuhan mental yang dominan, tugas kerja yang berlebih dan kurang teratur kerap menimbulkan masalah pada setiap individu seperti mudah lelah, stress dan 
sebagainya. Hal-hal tersebut dapat mempengaruhi kestabilan proses produksi yang merupakan salah satu indikator penilaian kinerja secara umum dalam seksi proses produksi di bagian Purified Terephtalic Acid (PTA).

\subsection{Perumusan Masalah}

1. Bagaimana mengukur variabel beban kerja dengan dimensi metode SWAT?

2. Bagaimana hubungan beban kerja mental dengan kinerja terhadap operator?

3. Bagaimana meningkatkan kinerja operator jika hasil terhadap pengukuran kinerjanya rendah?

\subsection{Tujuan Penelitian}

1. Bagaimana mengukur variabel beban kerja dengan dimensi metode SWAT?

2. Bagaimana hubungan beban kerja mental dengan kinerja terhadap operator?

3. Bagaimana meningkatkan kinerja operator jika hasil terhadap pengukuran kinerjanya rendah?

\subsection{Batasan Penelitian}

1. Penelitian difokuskan pada pengukuran tingkat beban mental kerja operator produksi di bagian Purified Terephtalic Acid (PTA). Penelitian dilakukan pada operator produksi di bagian Purified Terephtalic Acid (PTA) dengan jumlah 32 orang.

2. Pengukuran dilakukan dengan menggunakan dimensi metode SWAT.

3. Untuk variabel kinerja diukur dengan teori John Miner dengan 4 dimensinya yaitu kualitas, kuantitas, penggunaan waktu dalam bekerja, dan kerjasama dalam bekerja.

4. Pada penelitian ini, data diolah dengan menggunakan software SPSS versi 20.

5. Penelitian ini dilaksanakan pada April 2016 - Juli 2016.

\section{METODOLOGI}

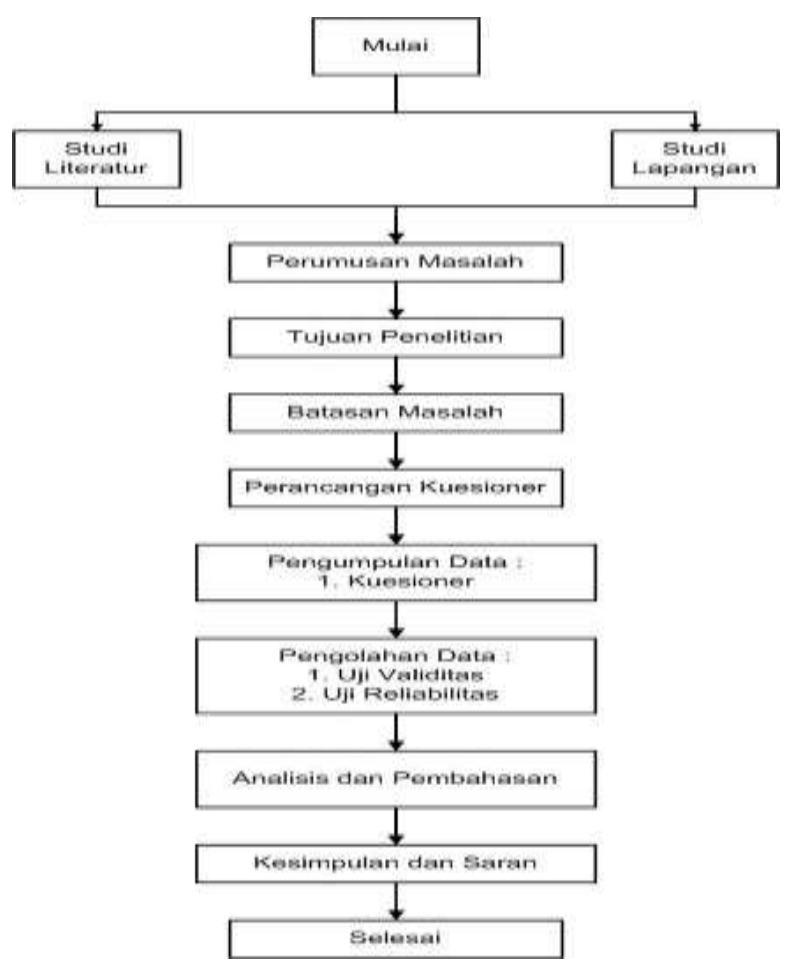




\section{HASIL DAN PEMBAHASAN}

Penelitian ini menggunakan dimensi dari metode SWAT (Subjective Workload Assessment Technique) sebagai acuan untuk variabel beban kerja mental. Peneliti menggunakan dimensi pada metode SWAT untuk menjadi indikator dalam kuesioner yang dibagikan kepada responden.

\subsection{Deskripsi Pekerjaan Responden}

Responden pada penelitian ini merupakan operator proses produksi bagian Purified Terephtalic Acid (PTA) di PT Mitsubishi Chemical Indonesia yang berjumlah 32 orang. Terdapat 2 plant (pabrik) pada proses produksi bagian Purified Terephtalic Acid (PTA) yaitu PTA-1 dan PTA-2 dengan masing-masing pabrik memiliki 16 orang operator yang dibagi menjadi 4 grup shift kerja, sehingga tiap shift kerja operator berjumlah 4 orang. Pekerjaan operator tiap shift- nya yaitu, DCS-Man, Sample, Others dan Daily Patrol.

Dibawah ini merupakan penjelasan pekerjaannya :

a. DCS-Man : Pekerjaan yang dilakukannya adalah memonitor dan mengontrol proses produksi dengan menggunakan komputer atau yang biasa disebut sebagai Distributed Control System.

b. Others : Melakukan pekerjaan reguler dan irreguler/pekerjaan spesial. Pekerjaan reguler yaitu pekerjaan yang sudah terjadwal yang biasanya dilakukan untuk perawatan alat/mesin sedangkan irreguler/pekerjaan spesial yaitu pekerjaan yang tidak ada pada jadwal reguler yang biasanya dilakukan jika ada permintaan khusus atau pada saat terjadi masalah.

c. Sample : Mengambil sampel produk yang sudah terjadwal setiap harinya dan juga sampel-sampel bahan kimia lainnya yang terdapat pada setiap alat tertentu yang sudah terjadwal maupun tidak terjadwal (sampel spesial).

d. Daily Patrol : Patroli keseluruhan pabrik dan mencatat kondisi alat pada buku daily patrol. Dari bagian daily patrol tersebut kita dapat mengetahui jika terjadi abnormalitas pada alat-alat yang ada di pabrik.

Tujuan dari pembagian tugas-tugas tersebut diantaranya untuk :

a. Menjaga kestabilan proses produksi.

b. Menjaga kualitas hasil produksi.

c. Lebih cepat mengetahui jika terjadi abnormal pada pabrik, baik itu berupa kerusakan pada alat/mesin maupun pada proses produksinya.

\subsection{Uji Instrumentasi (Uji Validitas dan Reliabilitas)}

Uji validitas ini menggunakan program SPSS versi 20 dengan cara mengkorelasikan masing-masing skor item dengan skor total sehingga didapatkan nilai $r$ hitung. Skor total item adalah penjumlahan dari keseluruhan item. Untuk nilai $r$ tabel kita bisa menggunakan Tabel $r$. Nilai $r$ tabel disesuaikan dengan jumlah sampel atau responden yang digunakan pada penelitian. Ketentuan dalam uji validitas ini yaitu jika nilai korelasi ( $\mathrm{r}$ hitung) tiap indikator lebih besar dari $\mathrm{r}$ tabel maka indikator/ item tersebut dinyatakan valid, sebaliknya jika $r$ hitung lebih kecil daripada $r$ tabel atau nilai korelasi negatif maka item tidak valid (Priyatno, 2011).

Di bawah ini merupakan hasil uji validitas kuesioner. 
Tabel 1. Hasil Uji Instrumentasi Validitas

\begin{tabular}{|c|c|c|c|c|}
\hline No. & Indikator & r tabel & r hitung & Keterangan \\
\hline A & \multicolumn{4}{|l|}{ Variabel Beban Kerja Mental (Mental Effort Load) } \\
\hline A1 & Beban Waktu (Time Load) & & & \\
\hline 1 & Saya memiliki waktu luang yang sedikit & 0,349 & 0,849 & Valid \\
\hline 2 & $\begin{array}{l}\text { Saya sering kali mendapatkan gangguan selama } \\
\text { melakukan pekerjaan }\end{array}$ & 0,349 & 0,777 & Valid \\
\hline 3 & $\begin{array}{l}\text { Saya sering kali mengerjakan dua/lebih pekerjaan } \\
\text { dalam waktu yang perrsamaan }\end{array}$ & 0,349 & 0,765 & Valid \\
\hline $\mathbf{A 2}$ & Beban Usaha Mental (Mental Effort Load) & & & \\
\hline 1 & $\begin{array}{l}\text { Saya membutuhkan konsentrasi tinggi dalam } \\
\text { menyelesaikan pekerjaan }\end{array}$ & 0,349 & 0,637 & Valid \\
\hline 2 & $\begin{array}{l}\text { Pekerjaan yang saya lakukan tidak menentu } \\
\text { datangnya }\end{array}$ & 0,349 & 0,817 & Valid \\
\hline 3 & $\begin{array}{l}\text { Pengambilan keputusan disaat terjadi masalah atau } \\
\text { kesalahan dalam bekerja }\end{array}$ & 0,349 & 0,839 & Valid \\
\hline A3 & $\begin{array}{l}\text { Beban Tekanan Psikologis (Psychological } \\
\text { Stress Load) }\end{array}$ & & & \\
\hline 1 & Pekerjaan saya memiliki tingkat resiko yang tinggi & 0,349 & 0,580 & Valid \\
\hline 2 & $\begin{array}{l}\text { Saya merasa tingkat kompensasi yang saya } \\
\text { dapatkan saat ini dapat mengurangi tekanan } \\
\text { pekerjaan saya }\end{array}$ & 0,349 & 0,890 & Valid \\
\hline 3 & $\begin{array}{l}\text { Merasa putus asa karena tidak mampu } \\
\text { menyelesaikan pekerjaan dengan baik }\end{array}$ & 0,349 & 0,810 & Valid \\
\hline $\mathbf{B}$ & Variabel Kinerja Operator & & & \\
\hline B1 & Kualitas & & & \\
\hline 1 & Saya melakukan pekerjaan dengan teliti & 0,349 & 0,661 & Valid \\
\hline 2 & $\begin{array}{l}\text { Saya melakukan pekerjaan sesuai dengan Standart } \\
\text { Operating Procedurs (SOP) yang ada }\end{array}$ & 0,349 & 0,741 & Valid \\
\hline 3 & $\begin{array}{l}\text { Saya dapat mengurangi tingkat kesalahan dari } \\
\text { waktu ke waktu }\end{array}$ & 0,349 & 0,832 & Valid \\
\hline $\mathbf{B 2}$ & Kuantitas & & & \\
\hline 1 & Saya mengetahui target hasil yang ingin dicapai & 0,349 & 0,931 & Valid \\
\hline 2 & $\begin{array}{l}\text { Saya memahami cara untuk mencapai hasil yang } \\
\text { diinginkan }\end{array}$ & 0,349 & 0,513 & Valid \\
\hline
\end{tabular}




\begin{tabular}{|c|c|c|c|c|}
\hline No. & Indikator & $\mathbf{r}$ tabel & r hitung & Keterangan \\
\hline 3 & $\begin{array}{l}\text { Karyawan bersedia apabila diberikan tugas } \\
\text { tambahan }\end{array}$ & 0,349 & 0,778 & Valid \\
\hline B3 & Penggunaan Waktu dalam Bekerja & & & \\
\hline 1 & Saya menyelesaikan pekerjaan dengan tepat waktu & 0,349 & 0,845 & Valid \\
\hline 2 & $\begin{array}{l}\text { Saya memiliki tingkat disiplin kehadiran yang } \\
\text { tinggi }\end{array}$ & 0,349 & 0,911 & Valid \\
\hline 3 & $\begin{array}{l}\text { Saya membutuhkan waktu untuk memonitoring } \\
\text { pekerjaan yang sedang saya lakukan }\end{array}$ & 0,349 & 0,705 & Valid \\
\hline B4 & Kerjasama dalam Bekerja & & & \\
\hline 1 & Saya menyelesaikan pekerjaan dengan tepat waktu & 0,349 & 0,861 & Valid \\
\hline 2 & $\begin{array}{l}\text { Saya memiliki tingkat disiplin kehadiran yang } \\
\text { tinggi }\end{array}$ & 0,349 & 0,852 & Valid \\
\hline 3 & $\begin{array}{l}\text { Saya mengetahui waktu kerja yang sesuai dengan } \\
\text { standar kerja yang ada }\end{array}$ & 0,349 & 0,681 & Valid \\
\hline
\end{tabular}

Tabel 2. Hasil Uji Instrumentasi Reliabilitas

\begin{tabular}{|c|l|c|c|c|c|c|}
\hline No. & \multicolumn{2}{|c|}{ Indikator } & rtabel & Cronbach's Alpha & N of items & Keterangan \\
\hline A & \multicolumn{2}{|c|}{ Variabel Beban Kerja Mental } & 0,6 & 0,690 & 3 & Reliabel \\
\hline A1 & Beban Waktu & rtabel & Cronbach's Alpha & N of items & Keterangan \\
\hline No. & \multicolumn{2}{|c|}{ Indikator } & 0,6 & 0,655 & 3 & Reliabel \\
\hline A2 & Beban Usaha Mental & 0,6 & 0,645 & 3 & Reliabel \\
\hline A3 & Beban Tekanan Psikologis & 0,6 & 0,623 & 3 & Reliabel \\
\hline B & Variabel Kinerja Operator & 0,6 & 0,633 & 3 & Reliabel \\
\hline B1 & Kualitas & 0,6 & 0,751 & 3 & Reliabel \\
\hline B2 & Kuantitas & 0,6 & 0,720 & 3 & Reliabel \\
\hline B3 & $\begin{array}{l}\text { Penggunaan Waktu dalam } \\
\text { Bekerja }\end{array}$ & Kerjasama dalam Bekerja & & &
\end{tabular}




\subsection{Beban Kerja Mental Operator Proses Produksi Bagian Purified Terephtalic Acid (PTA) di PT Mitsubishi Chemical Indonesian}

Dalam pelaksanaannya, beban kerja operator proses produksi bagian purified terephtalic acid (PTA) di PT Mitsubishi Chemical Indonesia dilihat dari job description yang ada. Beban kerja mental operator dapat dikatakan tinggi, karena pekerjaan mereka adalah pekerjaan yang berhubungan dengan bahan- bahan kimia yang berbahaya. Responden menanggapi pernyataan dalam kuesioner dengan rata-rata jawaban setuju dan sangat setuju. Hal ini dikarenakan operator proses produksi pada bagianpurified terephtalic acid (PTA) menganggap beban kerja mental mereka memang tinggi. Hasil tanggapan operator dapat dilihat pada tabel di bawah ini.

Tabel 3. Hasil Tanggapan Operator (Beban Kerja Mental)

\begin{tabular}{|l|c|c|c|}
\hline \multicolumn{1}{|c|}{ Dimensi } & $\begin{array}{c}\text { Skor Jawaban } \\
\text { Responden }\end{array}$ & $\begin{array}{c}\text { Skala Jawaban } \\
\text { Responden }\end{array}$ & $\begin{array}{c}\text { Persentase Jawaban } \\
\text { Responden }\end{array}$ \\
\hline $\begin{array}{l}\text { Beban Waktu } \\
\text { (Time Load) }\end{array}$ & 368 & Tinggi & $76,7 \%$ \\
\hline $\begin{array}{l}\text { Beban Usaha Mental } \\
\text { (Mental Effort Load) }\end{array}$ & 417 & Sangat Tinggi & $86,9 \%$ \\
\hline $\begin{array}{l}\text { Beban Tekanan Psikologis } \\
\text { (Psychological Stress Load) })\end{array}$ & 398 & Tinggi & $82,9 \%$ \\
\hline
\end{tabular}

\subsection{Kinerja Operator Proses Produksi Bagian Purified Terephtalic Acid (PTA) di PT Mitsubishi Chemical Indonesia}

Tabel 4. Hasil Tanggapan Operator (Kinerja Operator)

\begin{tabular}{|l|c|c|c|}
\hline \multicolumn{1}{|c|}{ Dimensi } & $\begin{array}{c}\text { Skor Jawaban } \\
\text { Responden }\end{array}$ & $\begin{array}{c}\text { Skala Jawaban } \\
\text { Responden }\end{array}$ & $\begin{array}{c}\text { Persentase Jawaban } \\
\text { Responden }\end{array}$ \\
\hline Kualitas & 413 & Sangat Tinggi & $86,0 \%$ \\
\hline $\begin{array}{l}\text { Kuantitas } \\
\begin{array}{l}\text { Penggunaan Waktu dalam } \\
\text { Bekerja }\end{array}\end{array}$ & 491 & Tinggi & $81,4 \%$ \\
\hline Kerjasama dalam Bekerja & 410 & Tinggi & $83,5 \%$ \\
\hline
\end{tabular}

\subsection{Analisis Korelasi Rank Spearman}

Dengan menggunakan metode analisis korelasi rank spearman, maka dapat diketahui korelasi atau hubungan antara variabel beban kerja mental dengan variabel kinerja operator yang sekaligus dapat menjawab pokok permasalahan dalam penelitian ini. Uji korelasi rank spearman tersebut dilakukan dengan bantuan program SPSS versi 20.0 untuk melihat tingkat hubungan dan nilai koefisien korelasi antara variabel beban kerja mental dengan variabel kinerja operator.

Beban kerja mental dalam penelitian ini adalah variabel independen dan kinerja operator adalah variabel dependen. Hipotesis dalam penelitian ini adalah : 
Ho = Tidak ada hubungan antara beban kerja mental dengan kinerja operator proses produksi bagian Purified Terephtalic Acid (PTA) di PT Mitsubishi Chemical Indonesia.

$\mathrm{Ha}=$ Ada hubunganantara beban kerja mental dengan kinerja operator proses produksi bagian Purified Terephtalic Acid (PTA) di PT Mitsubishi Chemical Indonesia.

Pengujian menggunakan uji dua sisi dengan tingkat signifikansi $\alpha=5 \%$. Dengan kriteria pengujian, Ho diterima jika signifikansi $>0,05$ dan Ho ditolak jika signifikansi < 0,05.

Berikut merupakan hasil perhitungan nilai korelasi rank spearman antara variabel beban kerja mental dengan variabel kinerja operator dengan menggunakan bantuan SPSS 20.0.

Tabel 5. Hasil Uji Korelasi Rank Spearman

\begin{tabular}{|c|c|c|c|c|}
\hline \multicolumn{5}{|c|}{ Correlations } \\
\hline & & & $\begin{array}{c}\text { Beban_Kerja } \\
\text { _Mental }\end{array}$ & Kinerja \\
\hline \multirow[t]{6}{*}{ Spearman's rho } & \multirow[t]{3}{*}{ Beban_Kerja_Mental } & Correlation Coefficient & 1,000 & $.755^{\prime \prime}$ \\
\hline & & Sig. (2-tailed) & . &, 000 \\
\hline & & $N$ & 32 & 32 \\
\hline & \multirow[t]{3}{*}{ Kinerja } & Correlation Coefficient & $.755^{m \pi}$ & 1,000 \\
\hline & & Sig. (2-tailed) &, 000 & \\
\hline & & $\mathrm{N}$ & 32 & 32 \\
\hline
\end{tabular}

**. Correlation is significant at the 0.01 level (2-tailed).

Kedua tabel output, nilai Sig. (2-tailed) output di atas sebesar 0.00, artinya lebih kecil dari 0,05. Sesuai dengan kriteria pengujian, apabila nilai signifikansi lebih kecil dari 0,05 maka Ho ditolak. Ho dalam penelitian ini adalah "Tidak ada hubungan antara beban kerja mental dengan kinerja operator proses produksi bagian Purified Terephtalic Acid (PTA) di PT. Mitsubishi Chemical Indonesia," ditolak. Sedangkan Ha dalam penelitian ini adalah "Ada hubunganantara beban kerja mental dengan kinerja operator proses produksi bagian Purified Terephtalic Acid (PTA) di PT Mitsubishi Chemical Indonesia," diterima.

Sementara itu nilai koefisien korelasi (rs) antara kedua variabel sebesar 0,755. Keeratan hubungan termasuk dalam kategori kuat, karena jika diinterpretasikan dengan interval kategorisasi kekuatan hubungan korelasi menurut Sugiyono, masuk dalam kategori kuat $(0,6-0,799)$.

Nilai koefisien korelasi yaitu $+0,755$. Nilai positif tersebut menandakan variabel beban kerja mental dan kinerja operator dalam penelitian ini berhubungan positif. Artinya, semakin tinggi beban kerja mental akan semakin tinggi kinerja operator.

\subsection{Uji Z}

Untuk menguji (penerimaan/ penolakan Ho) dapat dilakukan dengan membandingkan Z-hitung dengan Z-tabel atau juga dapat dilihat dari nilai signifikansinya. Untuk memperkuat keputusan dari hasil analisis dengan menggunakan korelasi rank spearman, untuk melihat nilai signifikansi penulis menggunakan uji Z. Terlebih dahulu dicari nilai $Z_{\text {hitung }}\left(\mathrm{Z}_{\mathrm{h}}\right)$ dan $\mathrm{Z}_{\text {tabel }}\left(\mathrm{Z}_{\mathrm{t}}\right)$ kemudian membandingkan keduanya.

$$
\begin{array}{rlrlrl}
\text { Zhitung } & =\mathrm{rs} \times \sqrt{ } \quad 1 & \text { Keterangan: } & \text { rs }=\text { koefisien korelasi spearman } \\
& =0,755 \times \sqrt{ } 32 & 1 & n=\text { jumlah sampel penelitian } \\
& =4,203 & &
\end{array}
$$


Dari hasil perhitungan $Z_{\text {hitung }}\left(Z_{h}\right)$ diperoleh nilai sebesar 4,203. Sedangkan nilai $Z_{\text {tabel }}\left(Z_{t}\right)$ didapat dengan rumus uji dua pihak dimana nilai taraf signifikansi $(\alpha)$ sebesar $5 \%$, yaitu:

$$
\begin{aligned}
\mathrm{Z}_{\text {tabel }} & =\mathrm{Z}_{\alpha / 2} \\
& =\mathrm{Z}_{5 \% / 2} \\
& =\mathrm{Z}_{0,025}
\end{aligned}
$$

Berdasarkan tabel kurva normal didapatkan nilai Ztabel sebesar 1,96.

Sesuai dengan masalah yang akan diteliti, dalam hal ini untuk melihat hubungan beban kerja mental dengan kinerja operator, peneliti mengajukan hipotesis sebagai berikut :

Ho : tidak ada hubungan yang signifikan antara beban kerja mental dengan kinerja operator

Ha : ada hubungan yang signifikan antara beban kerja mental dengan kinerja operator

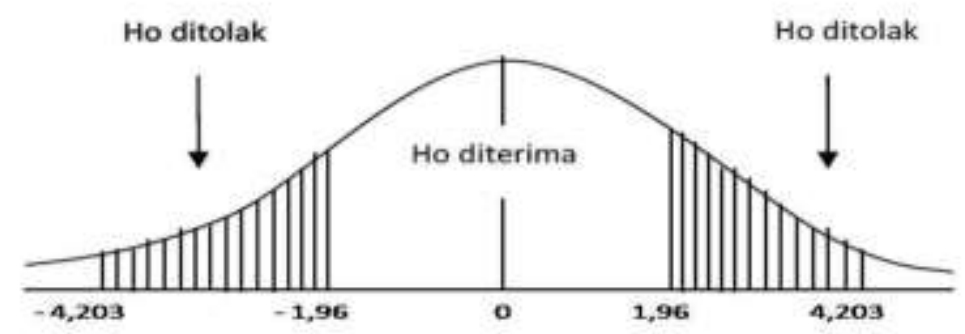

Gambar 2. Hasil Uji Hipotesis

Kriteria pengambilan kesimpulan :

Tolak Ho jika : $Z_{\text {hitung }}>Z_{\text {tabel }}$

Terima Ho jika: $Z$ hitung $<Z$ tabel

Dari hasil perhitungan di atas didapat nilai Zhitung sebesar 4,203 dan $Z_{\text {tabel }}$ sebesar

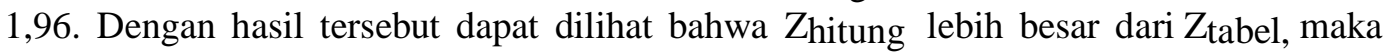
Ho ditolak dan artinya Ha diterima.

Maka kesimpulan stastistiknya adalah ada hubungan yang signifikan dan kuat antara beban kerja mental dengan kinerja operator. Dari pengujian di atas dapat diketahui bahwa hubungan antara variabel beban kerja mental dengan kinerja operator adalah positif kuat, hal tersebut dilihat dari koefisien korelasinya yang bernilai positif.

Beban kerja yang diberikan pun masih sesuai dengan kemampuan operator, sehingga menghasilkan kinerja yang baik. Selain itu kompensasi yang diberikan juga sesuai dengan beban kerja mereka. Sehingga dapat menyebabkan kinerja yang baik terhadap operator. Dengan kinerja yang baik, maka tujuan perusahaan dapat tercapai.

\section{SIMPULAN DAN SARAN}

\section{Kesimpulan}

a. Penelitian ini menggunakan dimensi dari metode SWAT (Subjective Workload Assessment Technique) sebagai acuan untuk variabel beban kerja mental. Peneliti menggunakan dimensi pada metode SWAT untuk menjadi indikator dalam kuesioner yang dibagikan kepada responden. Pernyataan dalam kuesioner beban kerja mental telah disesuaikan oleh peneliti sesuai dengan keadaan di tempat penelitian, sehingga dapat digunakan sebagai alat ukur yang relevan. Kemudian, hasil dari kuesioner diuji reliabilitas dan validitas agar dapat dipertanggungjawabkan secara ilmiah. Hasil dari penelitian ini menunjukkan bahwa beban kerja operator cenderung tinggi, ini bisa dilihat dari skala jawaban responden terhadap dimensi pengukuran 
beban kerja yaitu skala jawaban responden tinggi terhadap dimensi beban waktu, skala jawaban responden sangat tinggi terhadap dimensi beban usaha mental dan skala jawaban responden tinggi terhadap dimensi beban tekanan psikologis.

b. Hubungan yang ada antara beban kerja mental terhadap kinerja operator proses produksi di seksi purified terephtalic acid (PTA) di PT Mitsubishi Chemical Indonesia ini menunjukkan hasil yang signifikan diantara keduanya dimana kekuatan hubungannya kuat dan arah hubungannya positif, dengan nilai korelasi koefisien rank spearman-nya yaitu $+0,755$. Jawaban responden atas variabel beban kerja mental menunjukkan indikasi beban kerja kerja mental yang tergolong tinggi, di sisi lain jawaban atas variabel kinerja juga tergolong tinggi. Sehingga dapat disimpulkan bahwa operator proses produksi bagian purified terephtalic acid (PTA) di PT Mitsubishi Chemical Indonesia memiliki beban kerja mental yang tinggi dan menghasilkan kinerja yang tinggi.

c. Dalam penelitian ini, hasil dari penelitian menunjukkan bahwa kinerja operator dalam kondisi tinggi, hal ini bisa dilihat dari skala jawaban responden terhadap dimensi pengukuran kinerja yaitu dengan skala jawaban responden sangat tinggi terhadap dimensi kualitas, skala jawaban responden tinggi terhadap dimensi kuantitas, skala jawaban responden tinggi terhadap dimensi penggunaan waktu dalam bekerja, dan skala jawaban responden sangat tinggi terhadap dimensi kerjasama dalam bekerja. Dengan demikian tidak dilakukan perbaikan dalam hal kinerja.

\section{Saran}

Berdasarkan hasil penelitian ini, peneliti menyarankan beberapa hal sebagai berikut:

a. Penelitian lanjutan mengenai beban kerja bisa juga dilakukan di seksi lain dengan menggunakan metode yang sama. Dan juga bisa digunakan kembali ketika terjadi perubahan di seksi ini misalnya seperti terjadi perubahan jumlah karyawan baik itu pengurangan dan juga penambahan karyawan yang akan berpengaruh terhadap beban kerja.

b. Perusahaan harus mampu mengontrol perkembangan beban kerja operator dengan mengadakan survey berkala, untuk mengantisipasi beban kerja terlalu tinggi. Karena dari hasil penelitian, beban kerja operator proses produksi bagian purified terephtalic acid (PTA) tergolong tinggi.

c. Dengan kondisi operator yang rata-rata melakukan dua pekerjaan atau lebih dan memiliki waktu luang yang sedikit serta dengan adanya faktor-faktor lain dari internal maupun eksternal operator beban kerja dapat terus meningkat. Apabila beban kerja cenderung meningkat dan melebihi kemampuan para operator akan berakibat pada menurunnya kinerja karyawan. Sehingga peneliti menyarankan agar perusahaan dapat mengontrol beban kerja operator, sehingga kinerja operator dapat terus terjaga. Mengingat sampel yang terbatas, bagi penelitian selanjutnya sebaiknya dilakukan dengan sampel yang representatif sehingga generalisasi penelitian dapat dilakukan pada populasi yang lebih luas.

\section{DAFTAR PUSTAKA}

Artadi, Febri Furqon. 2015. Pengaruh Kepuasan Kerja dan Beban Kerja terhadap Kinerja Karyawan pada PT. Merapi Agung Lestari. Skripsi. Yogyakarta: UNY

Chaterina, Ruth. 2012. Hubungan Beban Kerja dengan Kinerja Karyawan Offshore pada Divisi Quality Assurance Quality Control di Pertamina Hulu Energi ONWJ LTD Jakarta. Skripsi. Depok: UI

Departemen Pendidikan Nasional. 2005. Kamus Besar Bahasa Indonesia. Jakarta: PT. Gramedia Pustaka Utama

Gibson, James L., Ivancevich John M. \& Donelly, Jr. James. 1985. Organisasi Jilid 1 Edisi Kelima. Jakarta: Penerbit Erlangga 
Hancock, P.A \& Meshkati, N. 1988. Human Mental Workload. Elsevier Science

Publisher B.V. Netherlands

Handoko, T. Hani. 2013. Manajemen Edisi 2. Yogyakarta : BPFE

Hart, Sandra G. and Staveland, Lowell E. Development of NASA-TLX (Talk Load Index): Result of Empirical and Teoritical Research. Jurnal. www.nasa.gov.id, diakses pada tanggal 28 Februari 2016

Hart, Sandra G. 2006. Nasa-Task Load Index (Nasa-TLX); 20 Years Later, http://humansystems.arc.nasa.gov/groups/tlx/downloads/HFES_2006_paper. pdf, diakses pada tanggal 28 Februari 2016

Hidayat, A.T. 2011. Analisis Pengaruh Shift Kerja terhadap Beban Kerja pada Pekerja di Islam Bandung

PT. Primarindo Asia Infrastructure, Tbk. Skripsi. Bandung: Universitas

Ivancevich, John.M. 2001. Human Resource Management. New York: Mc, Grow- Hill Companies

Memarian, Babak dan Mitropoulos, Panagiotis. 2011. Work Factors Affecting Task Demands of Masonry Works. Jurnal. Arizona State University

Panuju, Redi. 1995. Komunikasi Bisnis. Jakarta: PT Gramedia Pustaka Utama

Prasetyo, Bambang dan Lina, M. Jannah. 2012. Metode Penelitian Kuantitatif. Jakarta: PT Raja Grafindo Persada

Priyatno, Dwi. 2014. Mandiri Belajar Analisis Data dengan SPSS. Yogyakarta: Mediakom

Reid, G. B And Nygren, T. E. 1988. The Subjective Workload Assessment Technique: a scaling procedure for measuring mental workload. In P. A. Hancock and $N$. Meshkati (eds), Human Mental Workload, Amsterdam: North-Holland

Robbins, Stephen P. dan Judge, Timothy A. 2014. Perilaku Organisasi Edisi 12. Jakarta: Salemba Empat

Simamora, H. 2004. Manajemen Sumber Daya Manusia. Edisi Ke-3.Yogyakarta: STIE YKPN

Simanjuntak, Risma Adelina. 2010. Analisis Pengaruh Shift Kerja terhadap Beban Kerja Mental dengan Metode Subjective Workload Assessment Technique (SWAT). Jurnal. Yogyakarta: FT Institute Sains \& Teknologi AKPRIND Yogyakarta

Sudarmanto. 2009. Kinerja dan Pengembangan Kompetensi SDM (Teori, Dimensi Pengukuran, dan Implementasi dalam Organisasi). Yogyakarta: Pustaka Pelajar

Sugiyono. 2007. Metode Penelitian Administrasi. Bandung: PT Alfabeta

Tanireja, T. dan Mustafidah, H. 2014. Penelitian Kuantitatif. Bandung: Alfabeta

Wijono, Sutarto. 2010. Psikologi Industri \& Organisasi. Jakarta: Kencana

Yamin, Sofyan dan Kurniawan, Heri. 2014. SPSS Complete. Jakarta: Salemba Infotek. 